\title{
Parque Augusta (São Paulo/Brazil): From the Struggles of a Social Movement to Its Appropriation in the Real Estate Market and the Right to Nature in the City
}

\author{
Wendel Henrique Baumgartner 1
}

check for updates

Citation: Baumgartner, W.H. Parque Augusta (São Paulo/Brazil): From the Struggles of a Social Movement to Its Appropriation in the Real Estate Market and the Right to Nature in the City. Sustainability 2021, 13, 5150. https://doi.org/10.3390/su13095150

Academic Editor: Israa H. Mahmoud, Eugenio Morello, Giuseppe Salvia and Emma Puerari

Received: 6 April 2021

Accepted: 30 April 2021

Published: 5 May 2021

Publisher's Note: MDPI stays neutral with regard to jurisdictional claims in published maps and institutional affiliations.

Copyright: (C) 2021 by the author. Licensee MDPI, Basel, Switzerland. This article is an open access article distributed under the terms and conditions of the Creative Commons Attribution (CC BY) license (https:/ / creativecommons.org/licenses/by/ $4.0 /)$.
Department of Geography, Federal University of Bahia, Salvador 40170-110, Brazil; wendel_henrique@hotmail.com

\begin{abstract}
Through a dialectical approach, building a thesis, an antithesis and a synthesis, our goal in this article is to discuss the implementation of the Parque Augusta, in the center of São Paulo, Brazil. For years, an organized social movement struggled with the municipality and real estate developers for the protection of the park and its green area. The demanded and desired park, collectively designed and managed, physically structured on the principles of the nature-based solutions (NBS), should represent a victory. However, in a capitalist urban space, the future park has already been appropriated in the real estate market to enhance development values and to increase the density of its environs with the construction of new skyscrapers. In a city tagging its climate actions using NBS concepts, the project in implementation by the municipality has fewer NBS elements than the co-designed with citizens participation. Here we present the narratives of the park creation and some indicators about its appropriation, based on land use and real estate market prices. The theoretical critical perspective was fundamental to reveal the contradictions within the park construction, called attention to the consideration of the surrounding area in greening projects and promoted a synthesis towards the universalization of the right to nature in the city.
\end{abstract}

Keywords: Parque Augusta; nature-based solutions; social movements; appropriation of nature; green gentrification; right to nature

\section{Introduction}

The city, one of the greatest human achievements, an artifact par excellence, and an apparent denial of nature, becomes the main place for observing a new relationship between society and nature. Nature, as ideas, metaphors, metonymies, objects, amenities, realm, body, organism, among several possible interpretations, already reified and incorporated into social life throughout history, is now being (re)produced, (re)incorporated or (re)introduced, in scale, in the cities, through greening or renaturing urban projects, as green-blue infrastructures [1], ecosystem services [2], or nature-based solutions [3-6].

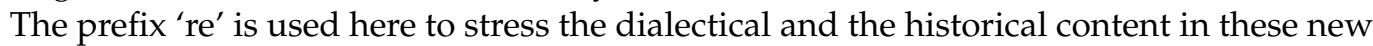
forms of (re)connection between city and nature [7-9]. This (re)valuation of nature in the city can be read, in a critical and dialectical way, as a possibility for a radical transformation of the urban space, towards the production of resilient towns [10], adapted to climate change and sustainable [11] in its existence and at the ordinary level of the everyday life. Nevertheless, the spaces of nature in the cities are, as well, an open arena for contradictions and appropriations of collective resources, demands and desires [12].

Since our main goal is to produce a right to nature in the city [13], founded upon social equity, spatial/environmental justice and just sustainability [14-16], through the construction of spaces of nature in our cities, related with nature-based solutions, it is still important to reveal some contradictions presented in the production of urban space [17].

If in the commonsense nature is opposed to culture and history [18,19], and consequently to the city [20], on the other side, there is a long tradition, especially within the 
dialectic's approaches [21-29] to understand nature also as a product of a long human history due to its incorporation into the social life. Fulfilled with ideologies, sentiments and expectations, the evolution of the ideas and concepts of nature [30,31], reveled and development by everyday life practices and techniques, shows possibilities to understand the role of nature the material-immaterial human production [32-34].

In this article, we investigated the history of the conception, creation and implementation of Parque Augusta, in the center of São Paulo/Brazil, after an intense dispute between real estate developers and a social movement, with the municipality trying to mediate the conflict [35]. The idea of this park, nourished by the residents and the civil society, demonstrates the importance of popular participation in the discussion and production of spaces of nature in the city, since the space is now protected, due to its green area. The vegetation was the key natural element to safeguard the park and include it in the green area system of the city, as a green space and public green infrastructure. During years of collaboration inside the movement, organized in 2013, a citizen's plan, co-created, co-designed and self-managed was produced after consulting residents, users and scholars [36]. In this plan, the park has a clear connection with the concept of the NBS, even if it was not defined as a nature-based solution (NBS). The ideas, design, concepts and infrastructures presented in this space, that remains as close as possible to nature, guaranteeing aspects such as permeability of urban soil to retain and purify water, indicate that the lack of the NBS concept does not invalidate the interpretation and use of the park and its content as a NBS.

However, there were several conflicts in the history of the Parque Augusta, not produced by the social movement or by the citizen's park proposal, but by the other agents in the production of urban space, such as the real estate developers and the municipal government [37]. The contradictions resulting from the clashes between possibilities of economic growth, environmental security and social equity are materialized in the urban landscape [38]. The commodification of the green spaces [39] and the appropriation of the successful results of the social movement fight and efforts [40] show that the economic sphere is still unbalancing the idea of sustainability.

It is important to mention that we do not intend to make an academic appropriation of the social movement struggles or to present a superficial and negative critique about the population participation in movements demanding greening projects and protecting spaces of nature in the cities. Our proposal is to build a critical reading showing how the real estate agents appropriate the achievements of these movements, to increase the values of estate developments. In the case of Parque Augusta, the area of the park is now safeguarded, but not its surroundings, which have no protective measures to avoid speculation and densification around the park. Unfortunately, contradictorily to the vision and desires of the collective movement, the park is being used in the real estate market, increasing housing and rental prices, creating an economic-based selection of who can live around the park. Understanding and revealing these processes are, in our perspective, fundamental to building a socially equal, greener and sustainable urban space [41].

\section{Notes about the Method}

The use of a dialectical approach could serve as an alert to future movements and contributes to raising awareness about the importance to include in the debate the surroundings of parks, green areas, NBS, and other definitions and concepts for environmental amenities and produced urban natural spaces, in an attempt to avoid speculation, displacement and spatial selectivity. In this way, considering the contradictions and a wider spatial idea about the natural spaces (beyond the objects in themselves) can contribute to uncover possible negative aspects of greening projects, and improve the universalization of the right to nature in the city.

The epistemological construction of the idea to support the conceptualization about the production of nature was built within the domain of dialectical knowledge [25]. Recently, the idea of a produced nature expands from the territory of dialectical studies and is reaching a broader audience [42-44]. Additionally, it has been gaining form, shape and 
application with the conception and acceptance of the nature-based solutions (NBS) [45,46], which are infrastructures built by society to mimic and reproduce the functioning nature, to offer ecosystem services and solve urban environmental problems.

The incorporation of the NBS in urban and environmental plans overcomes the idea that, in the city, nature is no longer an antithesis of socially produced space. On the contrary, it is an ally and a 'Work' [31] incorporated into the very existence and survival of the city. The Lefebvrian conceptualization of 'Work' and 'Product' can provide an important contribution in the necessity of upscaling the NBS. While a 'Work' is fulfilled with uniqueness and it is genuine and authentic in its own existence and meaning, the 'Product' is the result of mass production, an object easily reproduced. In our idea, the NBS should be conceived and implemented as a 'Work', when the object (the infrastructure, the plan) tries to capture the uniqueness of nature and becomes an intrinsic and undissociated part of the city, materializing the universality of natural cycles with local particularities and singularities of nature. However, we need to be cautions, because the NBS can also become a 'Product', when incorporated into the mass/industrial production, reproducing the same solution (infrastructure/plan) without taking consideration the singularities and particularities of places and local nature.

In our critical approach $[47,48]$, we cannot fail to reflect on the fact that the social production of nature in the city happens within the capitalist logic of production of space. In this direction, it is central to produce a careful and strong critical analysis to expose commonplaces, contradictions, and examine the burdens and benefits (who pays and who receives) of policies, plans and projects, in the direction to overrule individualism and egoism, in the name of 'eternal prosperity and supreme happiness' [47] (p. 101). A critical way of thinking, that incorporates the dialectical sphere in the discussion about naturebased solutions, demands to consider possible appropriations of NBS by the real estate market or the uneven access to the benefits of greening and renaturing projects, creating an unfair distribution of natural spaces among high and low-income citizens. In this text, we will seek to bring, in a dialectical tradition:

- A thesis, based in the analysis of the successful history of an urban park implementation, understood as a NBS, after several years of strong and combative actions of a social movement;

- An antithesis, to confront the results of the social demand for a park with its appropriation by the real estate market;

- The synthesis, where we can combine the two sides of the process (the production and the appropriation of the NBS), to transcend the contradictions, and, in our goal, to promote a universal right to nature in the city.

The association of the nature-based solutions and the promotion of the right to nature in the city [18] brings the urgency to consider the production and incorporation of nature in the urban space, as well as the relationships between its use and appropriation [49,50]. While some can effectively enjoy the benefits of living with nature, others (the poorest, more vulnerable, marginalized) end up being left out of the advantages, having to face nature as a problem (diseases, risks, dangers, etc.) [41]. The clashes between classes, communities, the winners and losers, the upper and lower-income residents, represent some conflicts that is fundamental to take into consideration when implementing a NBS. Revealing the contradictions and conflicts can bring light to the problems and make possible to solve and overcome the uneven access to nature and promote a real collective emancipation [26], inherent in the conception of the production and use of nature to safeguard and ensure urban life. Green spaces, the green-blue infrastructures, the NBS and other forms that natural spaces are taking shape cannot become a product or a commodity just for individual satisfaction $[13,14,26]$, where the incorporation and appropriation of nature is other marketing strategy $[39,51]$. 


\subsection{Presenting the Study Area}

Our time presents a visible clash between a consumerist and a sustainable culture, where cities and nature are in the center of this disputed arena, and both cultures, contradictory, were created and coexist in the sphere of the capitalist society. This fundamental characteristic of the present is the path to follow and build our dialectical analysis about the process that resulted in the creation and implementation of the Parque (Park) Augusta, in the central district of São Paulo, Brazil (Figure 1).

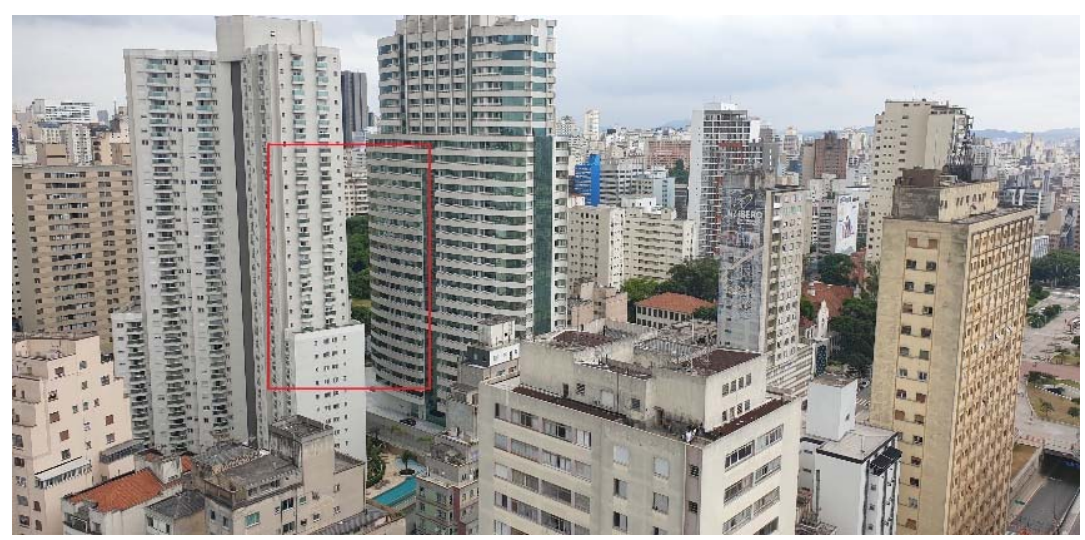

Figure 1. Parque Augusta in the city center of São Paulo (December/2020). Credits: Baumgartner.

It was a long and strong battle for an environmentally important and economically valorized urban land, with several U-turns in an emotional rollercoaster story. With 24,000 $\mathrm{m}^{2}$ the area contains one of the last reminiscences of Atlantic Rain Forest (Figure 2) in the heart of the most populous city in the Southern Hemisphere and of the World.

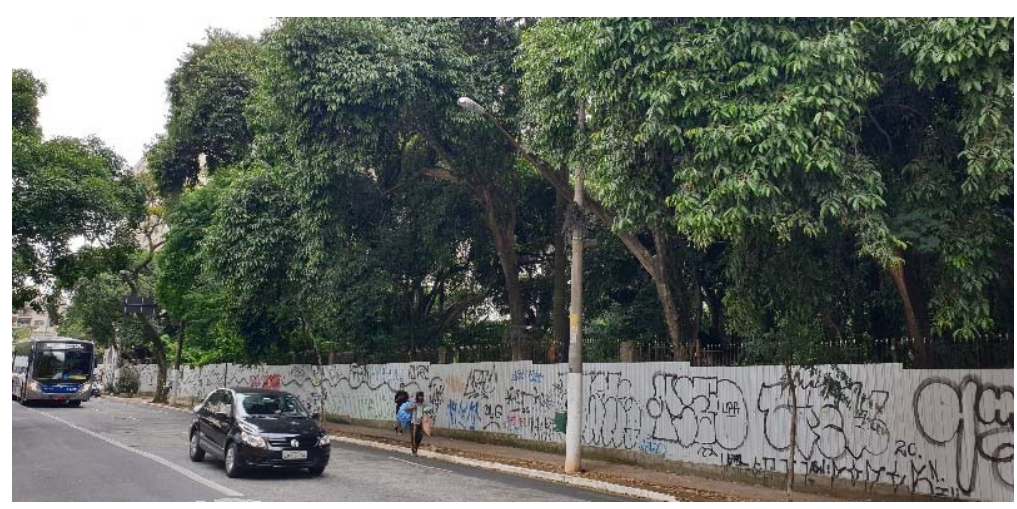

Figure 2. Landscape of the Parque Augusta (December/2020). Credits: Baumgartner.

The chronology of the disputed area shows an organized social movement in one side and real estate agents on the other, with the municipal government trying to intermediate the conflict (Table 1).

Several legal protections did not prevent the attempts of real estate developers to cut down the vegetation and build skyscrapers in the area. Just the intense participation the population throughout a self-organized movement succeeded to create the urban park, what was conceived, in their project with the principles of a nature-based solution in a densely built-up area of the city. Since 2020, for the municipality, the park is part of the system of green urban parks of the city, which is officially planed and managed has a nature-based solution [52]. 
Table 1. The chronology of the Parque Augusta. Credits: Baumgartner; [35].

\begin{tabular}{|c|c|}
\hline Year & Event \\
\hline 1969 & The schools which occupied the land were closed \\
\hline 1970 & The area was declared of public interest by the municipality \\
\hline 1975 & $\begin{array}{l}\text { The municipality did not pay the compensation and the land was divided in two } \\
\text { lots: } 7000 \mathrm{~m}^{2} \text { with public interest and } 17,000 \mathrm{~m}^{2} \text { for buildings projects }\end{array}$ \\
\hline 1986 & Without any construction, the area was declared Environmental Monument \\
\hline 1996 & Both lots were sold \\
\hline 2002 & The first project for a park was designed \\
\hline 2004 & The area is declared a Special Environmental Protection Zone \\
\hline 2012 & The lots were sold again to two real estate developers to build 3 skyscrapers \\
\hline 2013 & $\begin{array}{l}\text { The social movement occupied the area and opened a park. The municipality } \\
\text { approved a park. The owners had removed the occupants and closed the land }\end{array}$ \\
\hline 2015 & $\begin{array}{l}\text { The developers projected } 3 \text { towers. The area with public interest was reopened, } \\
\text { occupied and closed again. A negotiation began. }\end{array}$ \\
\hline 2016 & With the area closed, it was declared a Special Environmental Protected Zone \\
\hline 2017 & Conciliation hearings: the owners sold the land to the municipality \\
\hline 2019 & After 20 months, the deal was signed \\
\hline 2020 & Beginning of the park construction \\
\hline 2021 & The park remains closed \\
\hline
\end{tabular}

\subsection{Methodology}

The research design focused on the production of authorial examination of published documents and data; direct observation in the field; research about land and housing prices; and the dialectical construction of our discussion and results (Figure 3). The methodology is more qualitative than quantitative. For Brazil, since the last census with data at the individuals and house units' levels is from 2010, it is difficult to get an actual picture about, for example, the characteristics of the population living around the park (age, income or educational level, occupation, etc.) that will be important to support, statistically, the discussion about some of the themes such as exclusionary displacements [53,54], amongst others.

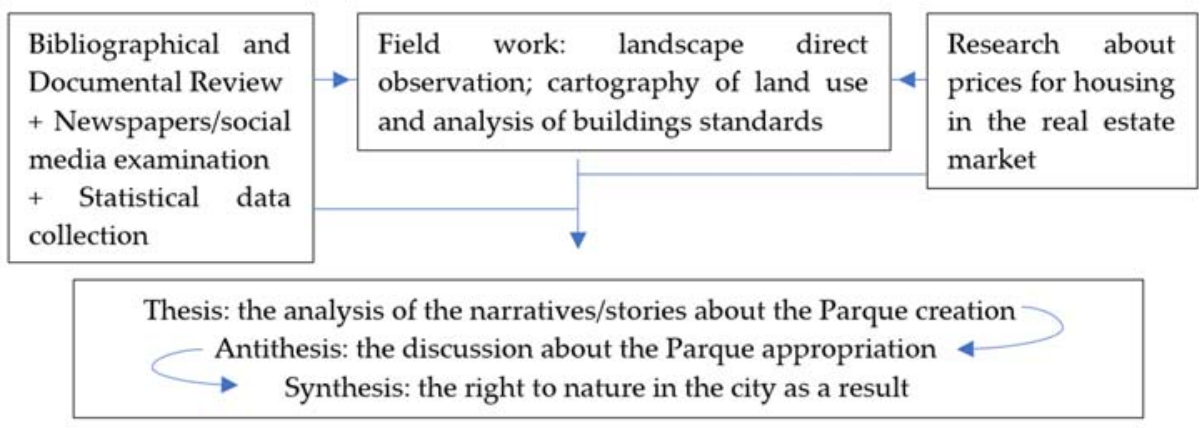

Figure 3. The research design. Credits: Baumgartner.

To overcome the lack of detailed data, we collected official general data to characterize the case study from the Brazilian Institute of Geography and Statistics [55] and Seade Foundation [56]; and legislation [57] and plans produced by the municipality about the park, such as the urban zoning map [58]. The data about the real estate market in the area around the park was important to visualize how the developers are appropriating the park in their strategies to produce a property value gain. The prices for housing purchase and the features of the estates were researched via real estate websites and the marketing material of the new developments [59-61]. The data we present about the price of housing unities available in the market is representing examples but are not statistically connected with all available unities for the city.

The qualitative research procedures, such as the topologic-morphologic analysis of the landscape, the analysis of marketing strategies for new developments in the area 
around the park and the data about the current prices in the real estate market produced some indicators about the profile of the desirable new residents and users for the park surroundings. The field trips also allowed the identification of possible spaces for new developments, increasing the already dense use of the area, visiting the new developments in the area. Due to the situation of the COVID-19 pandemic in Brazil and the sanitary protocols, we did not carry out interviews and inquiries with the local population, users, real estate customers and agents, government representatives, etc.

In May and December/2020, we carried out fieldworks to cartograph and identify the land use of lots and buildings in the immediate perimeter surrounding the Parque Augusta to confirm, or not, the appropriation of nature and the potentialities for a green gentrification process [12,38]. At that phase of the research, by direct observation, we cataloged 43 units with different typologies (individual and townhouses, multistory buildings, parking lots) and uses (residential, commercial, educational and institutional) around the park. Amongst these units, 17 are old, new (3) or under construction (1) residential buildings (some with commercial use on the ground floor), ranging from 10 to 33 stories; 2 are commercial buildings (from 8 to 29 stories); 1 is the campus of a private university; 1 hosts a police station; 2 are closed and unused parking lots; 16 are lower constructions (1 or 2 floors) with commercial or residential use (Figure 4). Amongst them, 6 are closed and without apparent use; 1 is for sale; 2 where demolished before December/2020 for the construction of a new residential building; 1 building in construction with 3 floors and mixes commercial and residential use.

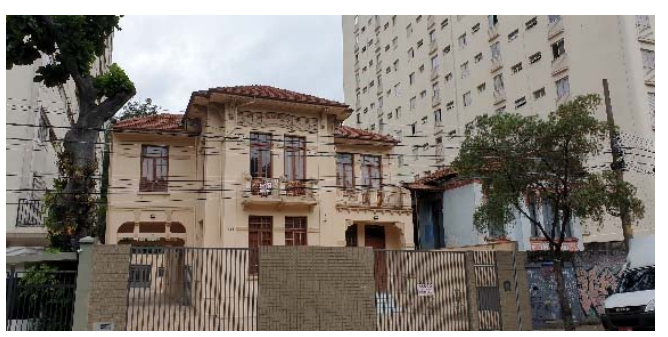

(a)

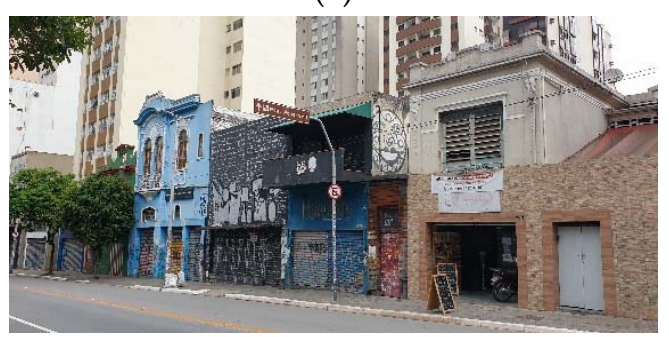

(c)

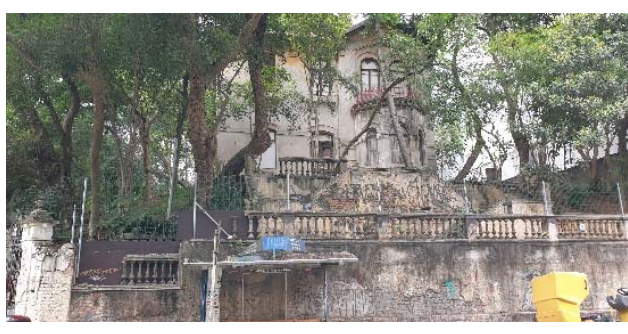

(b)

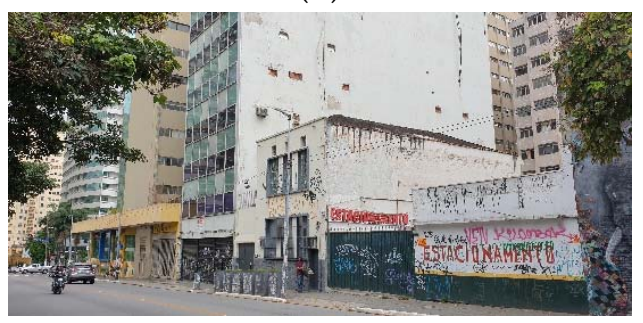

(d)

Figure 4. Aspects of the built environment around the park in December/2020. (a) A house for sale in front of the park ( $400 \mathrm{~m}^{2}$, BRL 8,550,000 or BRL 21,375 per $\left.\mathrm{m}^{2}\right)$; (b) the historical protected house was sold in an auction in 2018, but still has no use; (c) lower buildings at Rua Augusta. Just the first one is considered a historical monument and it is protected against demolition; (d) a closed parking lot, a potential area for new developments. Credits: Baumgartner.

Finally, before starting our explanation of this important victory of the social mobilization in favor of the Parque Augusta, it is important to clarify that this is an external study of the social movement (Movimento Parque Augusta), since we did not participate in the collective that demanded and proposed the park. Movimento Parque Augusta (Movement Augusta Park) is a self-organized social movement formed by three groups Aliados do Parque Augusta (Augusta Park Allies), Parque Augusta sem Prédios (Augusta Park without buildings) and Organismo Parque Augusta-OPA (Organism Augusta Park). OPA has the most extensive documented references about the history of the movement, including the production of two issues of a journal. Our analysis is based on the vast 
number of detailed documents, videos and social media texts that have been produced and organized, since 2013, by the movement [36,62-66]. We also checked for newspapers reports and news $[37,40,67,68]$; academic texts published in journals $[69,70]$; and social media $[71,72]$.

\section{Results and Discussions}

3.1. The Thesis: The Action of The Social Movement for the Creation of Parque Augusta and its Institutionalization as a NBS

In 2013, emerged an organized social movement around the claim of the area located between Augusta, Caio Prado and Marquês de Paranaguá streets and the Catholic University property, for the creation of an urban park. In the past, the area was occupied by two primary and secondary education institutions, and part of a university campus. After the demolition of the internal buildings, the land was used as a parking lot, for circus tent and as a space for shows $[69,73,74]$. The land was divided in two lots, where one was of public interest declared by the municipality. This dual ownership was the cause of the intense dispute about the area. Even though the area was already protected, in 2012, two real estate developing corporations decided to build three high residential towers in the area, or four smaller ones, or even a shopping mall [75].

Although other social efforts demanded the implementation of the Parque Augusta prior to the Parque Augusta Movement, it was this group that successful accomplished the task and have a well-documented history [62-66]. The movement was organized through festivals, meetings and other events, where participants with different backgrounds (residents, activists, scholars, artists) and expertise (traditional, academic or non-academic knowledge) were congregated in support for the maintenance of the space and its vegetation, located in the gray and highly dense center of São Paulo. The goals of the movement were the preservation of local vegetation, maintaining the land as a permeable space, contributing to the infiltration of rainwater and control of flooding, and the creation of a citizen's designed, self-organized and managed public park. These goals show the awareness of the social movement about what would later be defined as a NBS. The group defined itself as 'self-managed, horizontal and heterogeneous', achieved a great impact in media coverage, with a large repercussion and mobilization of public opinion about the importance of the area and the vegetation of the Parque Augusta for the discussions about the production of the city and the right to the city [76].

In 2013, the first year of the published actions of the movement, the documents show an internal concern of the group in relation to the subject of gentrification [63]. A debate about the theme was promoted by the journalistic project Architecture of Gentrification [77]. Nevertheless, this first effort and the knowledge about gentrification did not prevent the park being used to promote green gentrification in the surroundings, as we will explore in the next section of this article.

The park conception created by the movement should be contemplate the citizens participation in all phases, from the project design to the construction stage, finishing with a form of self-governance or management shared among the residents, users and general population. The park, projected, built and administered by the community could become a living laboratory for urban environmental planning, according with the movement [62]. To promote these conceptions, the movement occupied the land and a opened their version of the park in July/2013. In this process of occupation, infrastructures were built; furniture produced and acquired by the movement itself through donations of materials (gardening tools, chairs, tables, dumpsters, etc.) and were placed throughout the park; money (for maintenance, rent chemical toilet, etc.) was collect and people collaborated in the construction of the park's signage.

With the park opened and self-managed by the citizens group, various educational, cultural and political activities took place until December/2013, attracting academic, political and cultural personalities. Strong social and political pressure ensured the approval, on 23 December 2013, of the law that institutionalized Parque Augusta [57]. 
Unfortunately, just six days later, on 29 December 2013, the park's occupants were removed, the provisional infrastructure dismantled and the real estate developers managed, through private security agents, to retake the private portion of the park's land, walled and guarded, making it impossible the access even to the public portion of the area.

Throughout 2014, the gates remained closed and heavily controlled. The Movimento Parque Augusta continued to meet and held, on a weekly basis, cultural, political and educational activities on the sidewalks around the area. They reinforced the concept of a citizen's collective movement active in the production of the city, going beyond the simple idea of the park as physical space only. In their notion, the land of the park is part of an urban ecosystem, including springs of a hidden urban basin that flows under asphalt; promotes better quality of life for humans, animals; and regulates and improves water and air quality [62].

In the beginning of 2015, the park is reopened and occupied again by the movement. However, soon after the reoccupation, the corporations managed to repossess the land $[78,79]$. At that time, judicially and politically favorable to the construction companies, there was a judicialization of the social movement, with the criminalization of activists who occupied the land and the surrounding streets [80]. Due to the negative repercussion, the municipality tried a first draft of a public-private agreement, where the City Hall would sell the public part of the land to the real estate companies to build their skyscrapers projects [78]. In exchange, the developers must create and manage an open park to the public, which was a reduced version of what the original Parque Augusta should be. Just a small portion of the land will be kept opened, the rest of the area could be used for the construction of residential buildings and a private park for the future residents, where most of the vegetation would be preserved.

With this setback, the movement reaffirms the strategies of struggle and mobilization of public opinion against the public-private agreement. Strengthening the idea of creating a park that occupies $100 \%$ of the land and the importance to protect the vegetation granted the public opinion support to the movement. With this repercussion, the municipality reversed the decision to sell part of the land, and due to U-turn, the companies reopened the public portion of the land.

Already in 2017, the impasse continued to block a solution for the park. Between April and August, conciliation hearings were held between the three agents involved in the demand for the park: the municipality, the real estate companies and the social movement [35]. Among some proposals, the first decision had been the exchange of the private portion of the land in the Parque Augusta for a public area in the other part of the city. But, since the proposed area had a higher value in the market, this proposal had been not approved by the City Council. The new attempt for a solution involved the exchange of the park land for Bonds of Potential Constructed Area-BPCA (Certificados de Potencial Adicional de Construção-CEPACs, in Portuguese), issued by the City Hall $[67,68]$. The BPCA are papers issued by the municipality to capitalize the created soil in the real estate market, allowing constructions between a basic and a maximum potential build area, according to the Brazilian urbanist laws [81]. With the agreement, the previous owners of the private parcel in Parque Augusta, received an amount of Bonds that they can use to build in other developments, or sell in the stock market. The final agreement was signed in August 2018.

With this decision, the judicial imbroglio was finally solved. In the social networks (Facebook and Instagram), practically, all the comments celebrate the park creation and the fundamental involvement of the social movement, emphasizing the importance of the park and its remaining green area in the center of São Paulo, its role in floods and urban heat island prevention and as a recreational area.

The Parque Augusta Movement accepted the decision [67] and reiterated the importance of building a space with effective community participation in the park's planning and co-creation process and a shared management and. In fact, during 2017, the movement organized several popular polls (approximately 300 contributions) to establish the main aspirations of the population for the park and promoted several co-creation workshops 
to design the park. The citizens/community proposal for the implementation of the Augusta Parque [36] was designed and have proposals constructed with the participation of organized groups and individuals (scholars, artists and residents). In this plan for the park (Figure 5), the area should be sustainable, greener, self-sufficient, integrate educational and recreational areas and have a blue infrastructure to increase the contribution of the park to the problems of floods and drought in a climate adaptation strategy. The main actions and structures in the citizens proposal for the park should contain, mainly outside the area covered by the original vegetation:

- Photovoltaic panels to produce energy;

- Infrastructure to treat and transform used waters and waste into biogas;

- A system to collect selective solid garbage;

- A composting area on site;

- Furniture and signage system produced with natural and sustainable materials;

- An increased green area, recovered with local fruit trees, contributing to the maintenance of the fauna and the regeneration of the ecosystem functions of the place;

- Basic infrastructures (toilets, dog training space and educational areas);

- A reservoir for rainwater harvesting;

- A seedling nursery, producing new trees and plants for the park and the community.

- A space for urban agriculture and communal garden.

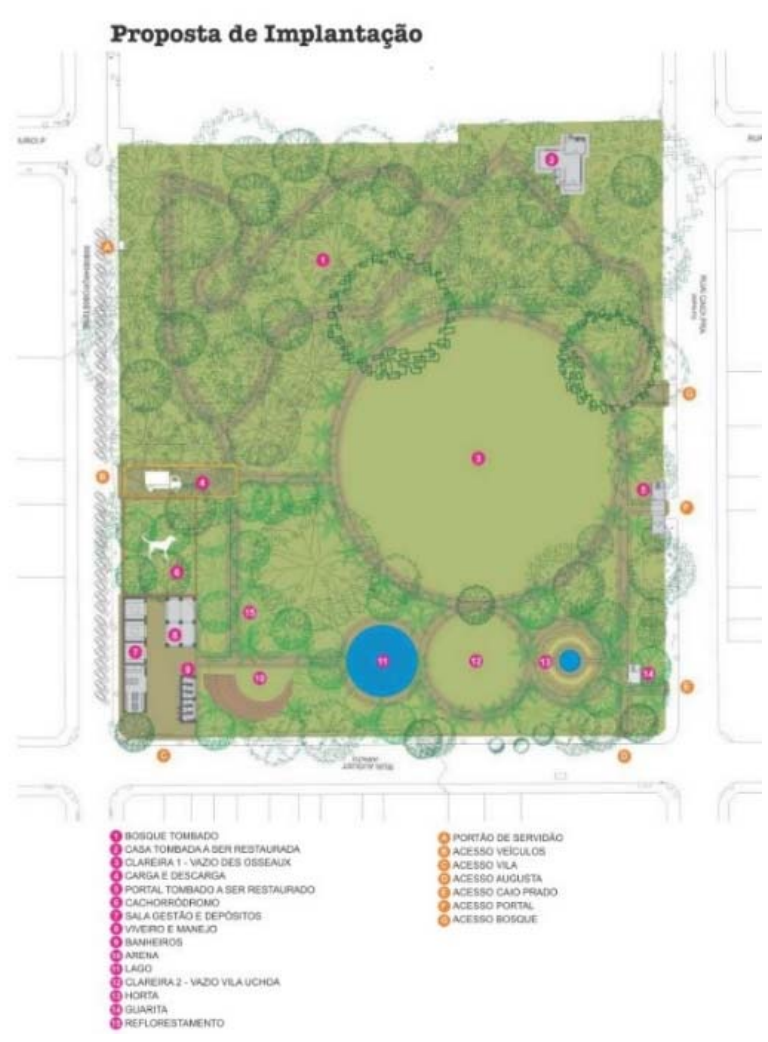

Figure 5. Citizens park project co-created by the Movimento Parque Augusta. Credits: [36].

Comparing these proposals presented in the citizen's plan for the Parque Augusta with some catalogues [3,82-84], all these measures and infrastructures can define the whole park as nature-based solution, albeit the term is not appearing the document published by the social movement [36].

In June 2020, São Paulo published its territorial plan of Sustainable Development Goals implementation, based, at least in the mayor's speech [52] (p.23), on the conception of nature-based solutions. According to this document, the Parque Augusta, amongst others municipal parks, is considered by the municipality as a green space and a green infras- 
tructure, joining a system of green areas that would be understood and configured as a strategy tackling climate change.

Within the 'Municipal plan for protected, green areas and open spaces' [52], the park and other green spaces are clearly defined as areas for provision of ecosystem or environmental services. In private areas, the plan projected a financial bonus program for the construction, restoration and maintenance of natural spaces that offer ecosystem or environmental services. In the city's conception, these services provided by the biodiversity present in the city have an aesthetic nature, but also are associated with the availability and control of water, soil and atmosphere quality, regulating the urban thermal sensation. Thus, the green and unpaved area would have some functions: filtering rainwater and regulate underground storage; promoting carbon sequestration and retention; improving air quality, reducing pollution rates; and regulating surface temperature, through evapotranspiration and direct shading. In addition, the park would be a space for sociability, recreation and a platform for educational activities, improving the indicators of habitability in the city.

Associating the assumptions of the plan and the potentialities observed in the Parque Augusta, considering the environmental sphere, the territorialization of following SDGs would be possible: 3 (health and well-being), 6 (drinking water and sanitation), 11 (sustainable cities), 13 (action against global climate change) and 15 (terrestrial life). The municipality also indicates that SDG 17 (partnerships and means of implementation) would be achievable in municipal parks.

However, the project of the park has a stronger partnership with the real estate developers than the social movements. The official project of the Parque Augusta (Figure 6) designed and approved by the City Hall will be managed by the former's private owners of the land, who are responsible for its implementation and maintenance for 2 years [85].

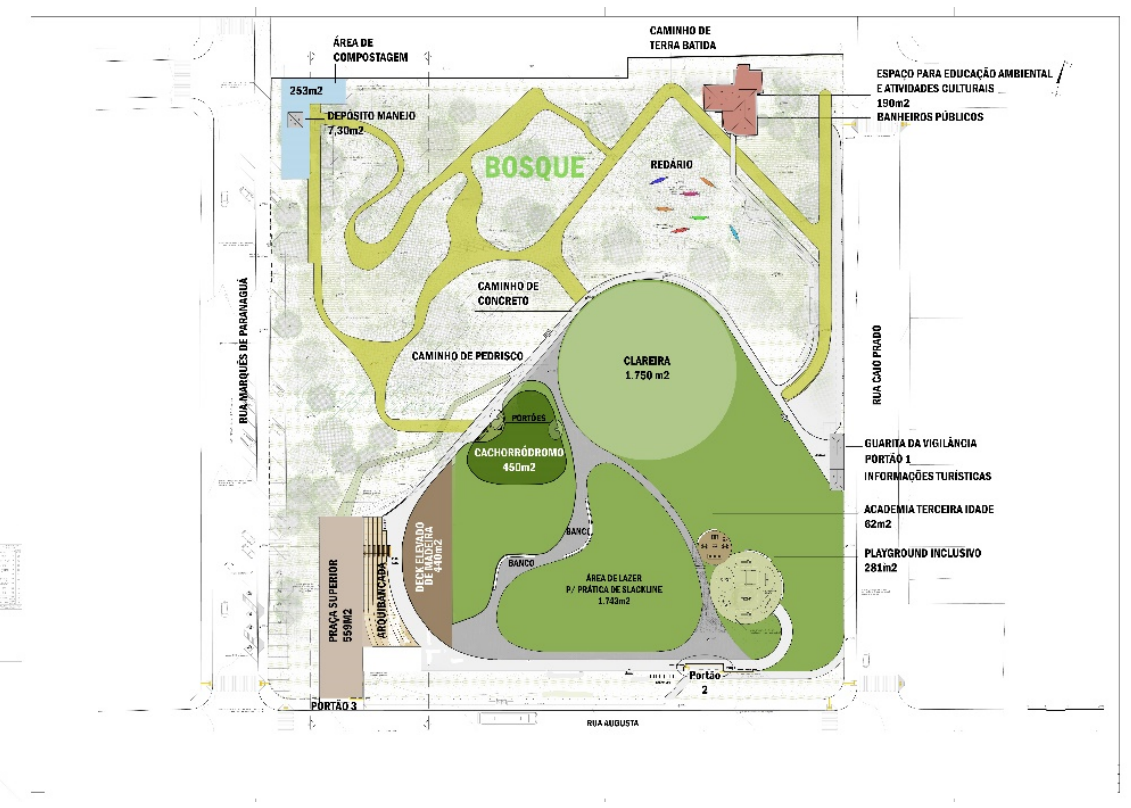

Figure 6. Official project for the park. Credits: [85].

Besides a dog training space (Cachorródromo), public toilets, composting area and seedling nursery, all the other 'attractions' (hammock lounge [redário], open gym for the elderly [academia da Terceira idade], slackline area, a grandstand [arquibancada], an elevated deck) were not in the scope of the citizens proposal for the park.

Several demands and strategies, including a much more sustainable and consistent with the NBS approach, presented in the community project, are not present in the official project produced by the municipality. Additionally, the project defines that $10 \%$ of the area can be impermeabilized, with some pavements constructed with concrete. This material 
could easily be replaced by some other type of material, increasing the permeability such as demonstrated in the NBS catalogues and standards [82,83].

In 2019, the official presentation of the project registered that it was showed to the social movement in 2017, but there is no information about any update or changing in the project with the movement [86]. In addition, the project is vague about the community participation in its designs, just informing that the suggestions from the population were received, but without further details about how many people participated and when/where the participation happened. The only sphere of the official project with clear citizen's involvement is the participation in a management committee. According to local regulations, the committee should control the planning and maintenance of the park and monitor the activities and events in the area. The local population (registered in the document as users) took part in the election, back in 2019, for four seats in a 2-year term, to form this group with members of the municipal government (presidency and other two seats), a member representing the park works, and another member from an organized social movement [87].

In March 2021, even with a simpler project in implementation, the bureaucracies solved and a local committee elected to follow the implementation and construction of the park infrastructures, the Parque Augusta remains closed. The works have not been completed and the inauguration date has been postponed since 2020. The expected date to open the gates for the population is July/2021, but there is already another conflict, involving the construction of a grandstand designed for art performances. Even if an amphitheater was present in the citizens proposal, it is now not desired by some local residents who does not want to have noise and higher number of visitors during cultural events in the park [88].

\subsection{The Antithesis: The Appropriation of Nature by the Agents of the Real Estate Market}

To dialectically confront the implementation process of the Parque Augusta, we take, as a premise, the fact that nature, materially and symbolically, is incorporated into the sphere of a capitalist world, where it is (re)produced as an instrumental rationality [89]. In the cites, from a set of intrinsic needs for humans and other forms of life, the values, the experiences and the spaces of nature are reified and commodified [90]. Converted into wishes and desires, transmuting its constitution as a value of use into value of exchange, nature is becoming another possibility for consumption, in a process that appear to be inherent to our society [91]. In the XIX century, Marx had already warned about the commodification of nature and its capitalist appropriation, indicating that it can be used as bait to capture, ironically, the essence of a person in the capitalistic society: its money [21].

In the contemporary city, highly artificialized places, nature is converted and perceived as a resource, a commodity or a service, and used to enhance premiums in the real estate market $[39,51]$. Since a price to live with nature is established, a difference in its accessibility and affordability, according to class or income, is also recognized. Even if all humans depend on nature to survive, and renaturing of cities is urgent and necessary, not all have the same capital to live with nature, or nearby. From luxurious condominiums to low-income housing projects, the spaces of nature are very different. While in high income urban or suburban neighborhoods' nature is well cared, produced for contemplation, relaxation and exhibition of prestige/privilege, in the low-income, vulnerable and marginalized areas, in the social or geographical peripheries of the capitalist city, the ' $\mathrm{raw}^{\prime}$ and not controlled nature is a synonym of risks, dangers and threats, such as floods or diseases. The appropriation of nature by real estate companies denies collective benefits, hiding illusions of comfort, satisfaction and sustainability in the individual life.

Having in consideration these statements, we can try uncovering how the Parque Augusta, a necessary but also a desirable space, have been appropriated by the real estate developers. The commodification of the park, from its physical nature to its image, happens in the immediate surroundings of it, and had started even before its official implementation. As explained before, to have the full ownership of the land where the park 
was planned, the municipality exchange (paid) the lot for Bonds of Potential Construction Area (BPCA). The number of certificates issued represents a potential 3.3 million $\mathrm{m}^{2}$ of constructed area, that can be used in several parts of São Paulo or even be sold in the regular stock market. Usually, the money received by the municipality in BPCA transactions is used to improve the basic urban infrastructure (sewage, water distribution, garbage collection, etc.) in areas of saturation or highly dense use. The strategy, at the surface, seems to be proper, since the municipality received the land without paying for it in advance, just had ceded future capital income. However, the Bonds issued overpriced the land in BRL 95 million (USD 24,1 million in the exchange rate of August/2018 or USD 16,5 million nowadays, due to intense devaluation of the Brazilian Real) [68]. It is important to remember, that even if the land had a contested private ownership, the area and the vegetation should be protected according to the municipal laws. On several occasions, documented in their webpage, the Movimento Parque Augusta complained about the lack of transparency in the financial agreements between the municipality and the developers [62].

But our biggest concern is the propagation of what some scholars are defining as green gentrification $[12,38,92,93]$ and is already punctually identified around the Parque Augusta, in three recent real estate developments in front of the park, but with a potential growth. These new developments will be identified as Development 1 (with one tower), Development 2 (with two towers) and Development 3 (with one tower).

The green gentrification can be the result of exclusionary displacement [53] or exclusion of the poorest from the benefits of environmental amenities [94]. The green gentrification materializes the supremacy of the production and consumption of nature as an individual or personal satisfaction project in the access of nature in the urban space. Ecological gentrification [95] was the concept used to represent the denial of access to natural spaces in the cities, based in class, income or social hierarchy, including the perspectives of homeless people about the nature. Several homeless are living in the streets around the park, being naturalized and included in the urban landscape without the minimal basic rights, and quite far away from the right to nature in the city. Comments in news or posts about the park revels the need to remove/transfer these homeless people from the Parque Augusta area to avoid depreciation of real estate vale and the infeasibility for families to use the future park.

The region, known as Baixo Augusta (Lower Augusta) has a popular commerce profile, and it was famous for its dancing/sex clubs, that are now partially shut down [74]. Several other commercial properties are also closed, not only because a possible property price reevaluation, but also due to bankruptcy during the COVID-19 crisis.

The actual valid urban zoning, from 2016 (Figure 7) [58], includes 3 of the park perimeters (Augusta and Marques de Paranaguá streets, and the limit with a university campus) as Areas for Urban Structuring Transformation (ZEU) and 1 perimeter (Caio Prado street) as a Centrality Zone (ZC). The park itself is a Special Environmental Protection Zone (ZEPAM). The ZEU foresees measures to increase the density, allowing high construction potentials without story limits. The ZC is defined as medium density area, with incentives for commercial and residential uses, with heights limited up to $60 \mathrm{~m}$.

Thus, according to this current zoning legislation, the areas of the two currently closed parking lots and 9 lower buildings ( 1 or 2 floors) are in the zone that allows high density. Four lower buildings are in the medium density zone. The height profile and the lower density of the park surroundings buildings, the current use, or its emptiness, indicate a great constructive potential in the area, with the replacement of individual houses, townhouses and parking lots by skyscrapers, fulfilling the projections of the urban zoning indicators. For example, in 2019, after the final decision about the park, a developer demolished a gas station and two townhouses to build a residential apartment tower, which is already conclude. This development has 24 floors and 250 units (from 67 to $125 \mathrm{~m}^{2}$ ). In another space, a former parking lot gave space, also in 2019, to a 27-story residential building with 216 units (ranging from 24 to $58 \mathrm{~m}^{2}$ ) [60]. 


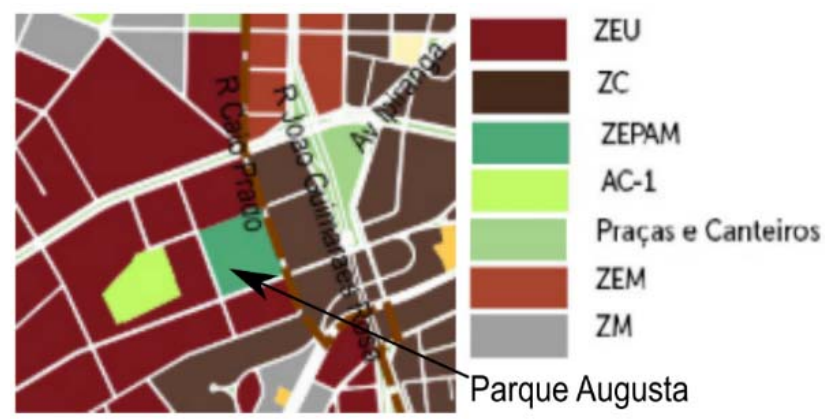

Figure 7. Extract from the zoning map of São Paulo center district. ZEU, Urban Structuring Transformation Zone; ZC, Centrality Zone; ZEPAM, Special Environmental Protection Zone; AC-1, recreational club; praças e canteiros, squares and flower beds; ZEM, Metropolitan Structuring Axis Zone; ZM, Mixed Zone. Credits: [74].

Besides the substitution of houses and others low-density used spaces for high residential developments, the prices of these new apartment's units are also an indicator of the valorization that the park brought to the area. Our survey on the prices of land, units and average value for constructed area (square meters- $-\mathrm{m}^{2}$ ), shows that the value of the constructed square meters, in the area surrounding the park increased from BRL 5522 (August/2018) to BRL 8817 (March/2021). The first value corresponds to the price on the date of the final agreement between the developers and the municipality $[59,67]$ and the second one, from March/2021, covers the average price for $\mathrm{m}^{2}$ (buying transactions) in the region where the park is located [68]. Besides the park, the only transformation in the area was the inauguration of a subway station in January/2018. Since the Brazilian Real suffered a large devaluation in the past years, we decide to present the values in the local currency, avoiding transferring the dollar devaluation to the prices that are practiced in 'reais' in the local real estate market. The conversion rate to American dollars was USD 1/BRL 3,93 (August/2018) and USD 1/BRL 5,76 (27 March 2021). In the same period, the accumulated inflation was $11.09 \%$, meaning that the price per $\mathrm{m}^{2}$ soared $143.73 \%$ above inflation.

Four new skyscrapers (in three different developments) are the first visual impact, recently built or nearing completion in the immediate perimeters of the park (Figure 8), are also priced for purchase with values above the neighborhood average values.

The Development 1 is most recent completed residential building has its marketing strategy focused on the direct relationship with the park, the urban renewal of the area and the gentrification of services and commerce [60]. In December/2020, we visited this development, which had gross (without upgrade options) values for $\mathrm{m}^{2}$ ranging from BRL 11,558.44 (unit on the 9th floor with $77 \mathrm{~m}^{2}$ ) to BRL 12,779.19 (unit on the 10th floor with $\left.66 \mathrm{~m}^{2}\right)$.

The above-average value is also visible in other properties, which offer free views to the Parque Augusta, such as the two towers in the Development 2. In the residential one, we found a unit with $158 \mathrm{~m}^{2}$ being sold for almost BRL 2 million, or BRL 11,958.81 per $\mathrm{m}^{2}$. Apartments in older buildings, from the 70s and 80s, are also being offered in the market, even without a direct view of the park at average prices around BRL 9,000.00 per $\mathrm{m}^{2}$.

The Development 3, in its last phase of conclusion [61], have units with $24 \mathrm{~m}^{2}$ being sold for BRL 15,208.33; units with $37 \mathrm{~m}^{2}$ for BRL 16,101.18 per $\mathrm{m}^{2}$; and units with $57 \mathrm{~m}^{2}$ for BRL 15,870.17 per $\mathrm{m}^{2}$. These values represent almost a $100 \%$ valorization above the average prices in the region (BRL $8,817 \mathrm{~m}^{2}$ ).

The neighborhood valorization and the attraction of new private investments to the area has been predicted by the municipality since the launch of the final and official project for the park [85]. 


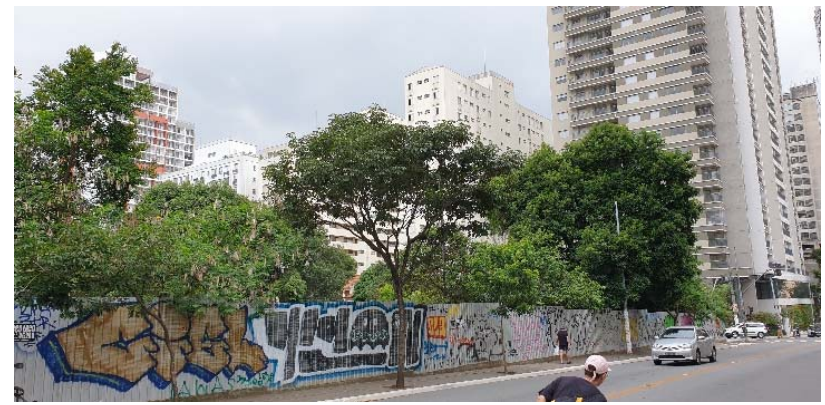

(a)

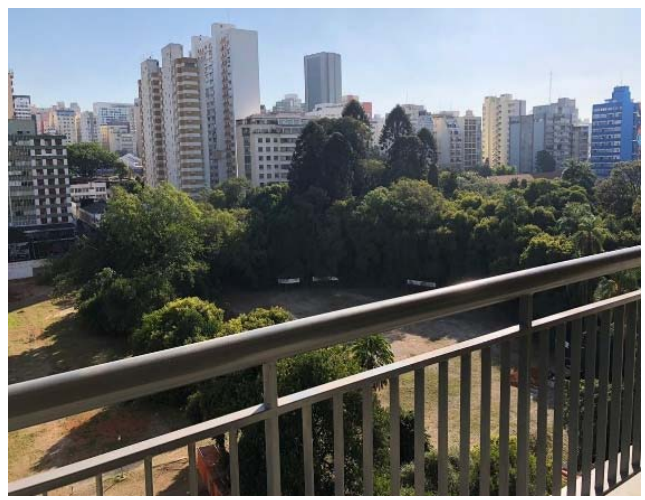

(b)

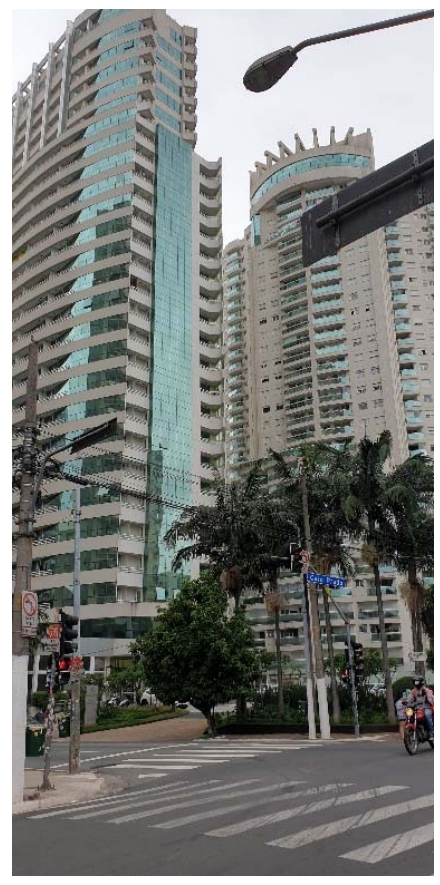

(c)

Figure 8. New developments in the environs of the park (December/2020). (a) The two newest building, on the right Development 1 and Development 3, on the left side of the picture; (b) The view from an apartment for sale; (c) Development 2 towers. Credits: Baumgartner.

To understand how those values promote an exclusionary displacement, and a potentially green gentrification, it is important to have a clear picture about the economic situation of the majority of São Paulo's population. According to the Brazilian Institute of Geography and Statistics (IBGE) [55], 12,325,232 people are living in the city and 21,6 million in its Metropolitan Area (50\% of the state population; approximately $10 \%$ of Brazil's population; and 33.3\% of the Brazilian GDP). The average income (2018) of formal workers in the city is 4,3 times the minimum wage (BRL 954 in 2018 and BRL 1,102 in 2021), but just $45.8 \%$ of its population has a formal (regular/legalized) job; $31.6 \%$ of the inhabitants were living (2010, last available data from the census) with less than a half of the minimum wage. The most recent data about income is from 2019, and shows that the medium income per person is BRL 48.40 per day, or BRL 1,472, 16 monthly (in favelas/slums the income is BRL 13.47 per day, BRL 409.71 monthly) [56,81].

The center of São Paulo (2.67 million inhabitants), where the Parque Augusta is located, has an average income of BRL 2,366 (63\% higher than the city), the highest amount of people with university or higher degree $(28.3 \%)$, the lowest rate of unemployment, the highest rate of formal jobs and the lowest infantile and juvenile population [56].

The differences of the general revenue in the city, considering formal/informal jobs and their distribution along São Paulo, show the gap between the average income of the inhabitants and the prices found in the real estate market for housing around the park. The profile of the inhabitants, that is represented in the context of the people engaged in the social movement [72], indicates another debate about green gentrification: are the environmental amenities inducing gentrification or inhabitants of gentrified areas are demanding better green spaces?

In the case of the Parque Augusta, the documents, the data and the field trips show that both processes running together. First, the implementation of the park has a direct connection with the profile of the area and its population, which has better access to the legal and media channels, than the population of lower income area. The residents and the 
activists of the social movement, due to their professional background, have a clear picture about their strategies, the importance of this park and its green area to the neighborhood and to the whole city. Connecting the conceptualization of the park with the NBS principles, matching the climate action by the municipality, was an important strategy to receive support from the public opinion, resulting in the park creation. Second, the immediate vicinity of the park has several potential lots for high density new developments (indicated by the actual urban zoning of São Paulo), and the prices in the market (above local average prices and medium income of the population), are enhanced by the implementation of the park. These indicators visible in the urban landscape and support by the prices survey, demonstrate the potential exclusionary displacement is already taking place, promoting what could be characterized as green gentrification.

\subsection{The Synthesis: The Right to Nature in the City and the NBS}

If we seek to build a synthesis, in the direction to promote a right to nature in the city [13], a first step is to uncover the history and the ideology that produces the city $[7,17]$ and the spaces of nature in the city $[25,26]$, to understand conflicts, class/racial privileges or struggles, such as like in a green gentrification process [38].

The construction of our proposal for dissemination of the right to nature in the city has three basic principles:

- A new praxis in the relationship with nature. In an optimistic conception of human action with nature, the right to nature in the city is not a right to exploit, dilapidate or consume nature for satisfaction of few individuals, but it is a process of collective emancipation to change the future perspectives for humanity in times of climate change. It is necessary to rethink daily life society's action on nature, from the crops to the cities, passing through commerce, industries and finances [96-98].

- The idea of nature for all citizens and not for customers. The imposition of individual satisfaction also led nature to be understood as an object of consumption and people as the consumer. The installation of consumption's ideology in all spheres of social life is one of the greatest perversions of the current period, with the commodification of nature and its services. One way to overcome this process is the defetishization and demystification of nature, understanding it as an element integrated to social life through history. In addition, it is essential to combat class, age, social and racial discriminatory access to nature in the city [99-101].

- To rethink the place of nature in the city. First, it is necessary to rethink the city not as an object, as a machine or an organism, but as the place of people's life, a human ecosystem, restoring collectiveness and empathy as the purpose of urban life. It is necessary to inhabit the city, to conscious participate in collective social life. Then, we can build a collective place to nature and to the nature-based solutions in the center of urban life [102-107].

The Praxis: 10 Strategies to Promote the Right to Nature in the City

The optimistic or utopic view of the relationship between urban society and nature is based on the urgency of the physical presence of natural spaces throughout the city, opened and accessible for all inhabitants or communities, despite income, classes, race or age. To achieve this goal, the following propositions were elaborated, considering necessary:

1. To create a right to nature in the city, as a collective right, not dissolving history or the city to return to a primitive nature. Nature can also not be reduced to a view, a panorama or a landscape.

2. To destroy the ideology of consumption of nature and urban spaces, in the direction to renew an innovative and creative freedom to produce a new real sustainable urban humanism and urbanism, considering all aspects of sustainability.

3. To transform the access to natural spaces in an accessible and affordable essential right. Nature is necessary for everyone, regardless of income and address. Nature cannot be a luxury commodity neither an object of decoration. 
4. To reaffirm the public aspect of nature, changing the current practice in which some high-income real estate developments have natural reserves in their areas, a space restricted to their residents, while in the poorest areas of cities the benefits of nature are denied, with, for example, in the absence of parks and green areas and the transformation of urban rivers in sewage. Preservation and production of nature and nature-based solutions in the city must be universal.

5. To consider the totality of nature in the city, overcoming its reduction as a synonym for green areas. Nature should be understood beyond trees, shrubs and grasses in the urban plans. The right of nature in the city must be expanded as the right to air, soil and water of good quality.

6. To understand the nature in the city as part of human work and history, overcoming the idea that nature in the city is a refuge for nature that no longer exists or an enclave in the urban fabric protected with a dome and separate from city life. Today nature is incorporated into human urban life. Therefore, the spaces of nature in the city must be used and lived, integrated in the everyday life. It is necessary to socialize its use, making nature a meeting place.

7. To promote ideas of nature-based solutions and blue-green urban infrastructures, radically transforming the cities, financing the incorporation of sustainable practices, especially in the poorest and vulnerable countries. Having green cities in some rich or high developed places will not create a resilient urban world.

8. To establish the connection with nature under the guidance of the concept of value of use and not exchange value. If nature is understood as a value of use it should not be commodified or commercialized, for example by real estate developers to enhance premiums in their properties. This will avoid green gentrification, spatial and economic segregation in the access to nature in our cities. There would be an appreciation of nature for its content, used by society, incorporated into the territory and benefiting all people.

9. To revel the perversion of neoliberal and public-private associations, where the public pays the burdens and the private sphere receives the bonus.

10. To understand the nature in the city dialectally, making it visible the history and the conflicts of the relations between society and nature, to overcome the traditional dichotomy between the city and nature.

\section{Some Conclusions and Final Considerations}

The project of the Parque Augusta produced by the social movement, with citizen's participation, had several principles and infrastructures which can define it as a naturebased solution, despite not using the term in the document. This collective design is much more integrated with nature, from its lake to the enhanced green area, but was not chosen by the São Paulo city's government to be implemented in the area. The official project in execution, designed by the municipality and constructed by the real estate developers who sold the land, although it is integrating a climate action, where the nature-based solutions are a key concept, has fewer physical elements of a NBS in its design. There is no space for rainwater harvesting, such as a lake or pond, the reforestation and other greening actions are vague and have more constructed and paved surfaces.

Considering how it was designed and co-created, the perspectives of a self-managed park and the NBS conceptualization, the project presented by the Movimento Parque Augusta was a much better choice for the area.

In our critical perspective, both projects are deficient in an integrated vision with the surroundings and the homeless people who live around the park. The integration and the participation of the homeless should be important to the construction of the park. Of course, the ideal solution will be the distribution of houses for them, but since this is not foreseen in the near horizon, due to deficiencies of public policies and social affordable housing projects, the homeless will be living around and inside the park. Regrettably, for some future users and inhabitants, they are and will be a problem, when using the park in their 
everyday life. Throughout the analysis of the content in some comments posted in social media (Facebook and Instagram) about the park creation, the problems of security and social selection is quite evident. Even without statistical accuracy, those comments provide some points for further discussion about the Parque Augusta, and other parks and open public green areas, since the fear and discomfort with diversity in public Brazilian spaces is a common felling [108]. The widespread and easiest solution have been fencing and gating the green spaces and public parks, controlling schedules and their access. As well, the integration of homeless people in the debate about the NBS, and other conceptual framework for projects designed to produce greener and resilient cities, is still an area for improvement.

Additionally, both projects did not incorporate instruments to prevent land speculation, fast values enhancing in housing prices, population displacement or green gentrification. Several instruments available in the Brazilian urban legislation, especially those in the 'Estatuto da Cidade' (City Statute) [81] were not taken into consideration to tackle, through an alternative to the current urban zoning, the increased construction potentials around the park, the liberation in the amount of floors and heights for new developments in three perimeters of the park, what can improve the densification of the in the immediate surroundings of the Parque Augusta.

In our conclusion, the focus just in the object (the park, the NBS, etc.), losing a wider spatial perspective, with the inclusion of the surroundings and the whole neighborhoods, can produce gaps where the real estate capital will prosper and appropriate the benefits of greening and renaturing projects. To promote social, environmental justice and the right to the nature in the city, the action of real estate developers must be controlled and regulated, otherwise the land and housing prices will rise. Exclusionary displacement, spatial selectiveness and green gentrification means less diverse urban environment. These side effects are contradictory with the ideas behind the NBS, the SDGs and other greening projects which reinforce the importance of diversity. However, in the urban space, the biodiversity must include the socio-diversity, as well.

A dialectical approach to understand the (re)production of urban space and the (re)production of nature in the city is fundamental to uncover the contradictions and conflicts, rooted in the urban fabric and visible in the landscape. As a theoretical perspective, it brings other layers of complexity to the debate about the scope of nature-based solutions and how them can reach and be beneficial for more people. The construction of a synthesis, more than a practical compromise between the production and the appropriation of nature, allowed us to thing further, establishing principles for a co-existence of nature and city in the same space and launch perspectives about the access to nature.

Climate change adaptation and life during/post the COVID-19 pandemic demonstrate how important and valuable nature in the city can be. The construction of a better, sustainable and collective world will be possible, dialectally, understanding the production of urban and natural spaces and the universalization of the right to nature in the city to all inhabitants, despite color, age, race, social-economic situation and geographical position on the city. The right to nature in the city is a right for humans to live and prosper with nature and for nature to exist and flourish with humans.

Funding: This research received no external funding.

Institutional Review Board Statement: Not applicable.

Informed Consent Statement: Not applicable.

Data Availability Statement: Statistical Data provided by the Brazilian Institute of Geography and Statistics (IBGE) with open access are available in www.ibge.gov.br (accessed on 16 March 2021).

Conflicts of Interest: The author declares no conflict of interest. 


\section{References}

1. Kozak, D.; Henderson, H.; Mazarro, A.C.; Rotbart, D.; Aradas, R. Blue-Green Infrastructure (BGI) in Dense Urban Watersheds. The Case of the Medrano Stream Basin (MSB) in Buenos Aires. Sustainability 2020, 12, 2163. [CrossRef]

2. Birkhofer, K.; Diehl, E.; Andersson, J.; Ekroos, J.; Früh-Müller, A.; Machnikowski, F.; Mader, V.L.; Nilsson, L.; Sasaki, K.; Rundlöf, M.; et al. Ecosystem services—current challenges and opportunities for ecological research. Front. Ecol. Evol. 2015, 1-12. [CrossRef]

3. EC (European Commission). Towards an EU Research and Innovation Policy Agenda for Nature-Based Solutions and Re-Naturing Cities; Publications Office of the European Union: Luxembourg, 2015. [CrossRef]

4. Colléony, A.; Shwartz, A. Beyond Assuming Co-Benefits in Nature-Based Solutions: A Human-Centered Approach to Optimize Social and Ecological Outcomes for Advancing Sustainable Urban Planning. Sustainability 2019, 11, 4924. [CrossRef]

5. Naumann, S.; Davis, M.; Iwaszuk, E.; Freundt, M.; Mederake, L. Addressing Climate Change in Cities-Policy Instruments to Promote Urban Nature-Based Solutions; Sendzimir Foundation: Warsaw, Poland, 2020.

6. Mahmoud, I.; Morello, E. Co-creation Pathway for Urban Nature-Based Solutions: Testing a Shared-Governance Approach in Three Cities and Nine Action Labs. In Smart and Sustainable Planning for Cities and Regions, Green Energy and Technology; Bisello, A., Ludlow, D., Vettorato, D., Baranzelli, C., Eds.; Springer: Cham, Switzerland, 2021; pp. 259-276. [CrossRef]

7. Mumford, L. The City in History: Its origins, Its transformations, and Its prospects; Harcourt, Brace and World: New York, NY, USA, 1961.

8. Glacken, C.J. Huellas en la playa de Rodas. Naturaleza y cultura en el pensamiento occidental desde la Antiguedad hasta finales des siglo XVIII; Ediciones del Serbal: Barcelona, Spain, 1996.

9. Férnandez-Armesto, F. Civilizations. Culture, Ambition, and the Transformation of Nature; The Free Press: New York, NY, USA, 2001.

10. Weichselgartner, J.; Kelman, I. Geographies of resilience: Challenges and opportunities of a descriptive concept. Prog. Hum. Geogr. 2015, 39, 249-267. [CrossRef]

11. Sachs, J. The Age of Sustainable Development; Columbia University Press: New York, NY, USA, 2015.

12. Anguelovski, I.; Connolly, J.J.T.; Pearsall, H.; Shokry, G.; Checker, M.; Maantay, J.; Gould, K.; Lewis, T.; Maroko, A.; Roberts, J. Why green "climate gentrification" threatens poor and vulnerable populations. PNAS 2019, 116, 26139-26143. [CrossRef]

13. Henrique, W. O direito a natureza na cidade; Edufba: Salvador, Brazil, 2009.

14. Gilbert, L. Social Justice and the "Green" City. Rev. Bras. Gest. Urbana 2014, 6, 1-18. [CrossRef]

15. Harvey, D. Social Justice and the City; University of Georgia Press: Athens, OH, USA, 1973.

16. Agyeman, J.; Bullard, R.D.; Evans, B. (Eds.) Just Sustainabilities: Development in an Unequal World; Taylor \& Francis: London, UK, 2012.

17. Lefebvre, H. The Production of Space; Blackwell Publishing: Oxford, UK, 1991.

18. Henrique, W. O direito à natureza na cidade. Ideologias e práticas na história. Doctoral Thesis, Doctorate in Geography-State University of São Paulo, Rio Claro, Brazil, 24 September 2004.

19. Lenoble, R. Histoire de l'idée de nature; Éditions Albin Michel: Paris, France, 1969.

20. Kos, D. Nature in the city or the city in nature? Urbani Izziv 2008, 19, 129-132. [CrossRef]

21. Marx, K. Capital - A Critique of Political Economy, Volume I, Book One: The Process of Production of Capital; Penguin Classics: London, UK, 1992.

22. Engels, F. Dialectics of Nature; Lawrence and Wishart: London, UK, 1939.

23. Marsh, G.P. Man and Nature: Or Physical Geography as Modified by Human Action; Charles Scriber: New York, NY, USA, 1874.

24. Reclus, É. Du sentiment de la nature dans le societés modernes et autres textes; Édition Premières Pierres: Paris, France, 2002.

25. Smith, N. Uneven Development: Nature, Capital, and the Production of Space; University of Georgia Press: Athens, OH, USA, 2008.

26. Harvey, D. Justice, Nature and the Geography of Difference; Blackwell Publishers: Oxford, UK, 1996.

27. Leff, E. Racionalidad ambiental. La apropiación social de la naturaleza; Siglo XXI Editores: Ciudad de México, México, 2004.

28. Kovel, J.; Löwy, M. Ecosocialist Manifesto. Available online: http://green.left.sweb.cz/frame/Manifesto.html (accessed on 16 March 2021).

29. Löwy, M. Why Ecosocialism: For a Red-Green Future. Available online: https://greattransition.org/publication/whyecosocialism-red-green-future (accessed on 16 March 2021).

30. Whitehead, A.N. The Concept of Nature; Cambridge University Press: Cambridge, UK, 1955.

31. Casini, P. As Filosofias da Natureza; Presença: Lisboa, Portugal, 1975.

32. Castree, N. Marxism and the Production of Nature. Capital Class 2000, 24, 5-36. [CrossRef]

33. Castree, N.; Braun, B. (Eds.) Social Nature: Theory, Practice, and Politics; Blackwell Publishers: Oxford, UK, 2001.

34. Loftus, A. Everyday Environmentalism: Creating an Urban Political Ecology; University of Minnesota Press: Minneapolis, MN, USA, 2012.

35. Marques Júnior, J.J. Parque Augusta no Município de São Paulo: Instituições estatais e não estatais envolvidas na consolidação desse equipamento urbano e as dinâmicas de negociação. Cadernos Jurídicos 2019, 52, 91-105.

36. Movimento Parque Augusta. Parque Augusta: Proposta de Implementação. Available online: https://drive.google.com/file/d/ 1mJzJvj1LOzPt9Zp4b_0ZGZ6v0nvzJQP4/view (accessed on 16 March 2021).

37. Carvalho, F. Parque Augusta, nova área verde de São Paulo e "negócio da China" para construtoras. Available online: https: / / brasil.elpais.com/brasil/2017/07/18/politica/1500413441_128758.html (accessed on 24 March 2021).

38. Gould, K.A.; Lewis, T.L. Green Gentrification. Urban Sustainability and the Struggle for Environmental Justice; Routledge: New York, NY, USA, 2017. 
39. Henrique, W. A cidade e a natureza: A apropriação, a valorização e a sofisticação da natureza nos empreendimentos imobiliários de alto padrão em São Paulo. GEOUSP Espaço e Tempo 2006, 10, 65-77. [CrossRef]

40. Castilho, I. Parque Augusta, luta coletiva a um passo da vitória. Available online: https://outraspalavras.net/blog/parqueaugusta-luta-coletiva-a-um-passo-da-vitoria / (accessed on 24 March 2021).

41. United Nations Human Settlements Programme (UN-Habitat). World Cities Report 2020; United Nations Human Settlements Programme: Nairobi, Kenya, 2020.

42. Chen, W.Y.; Yong Hu, F.Z. Producing nature for public: Land-based urbanization and provision of public green spaces in China. Applied Geography 2015, 58, 32-40. [CrossRef]

43. Angelo, H. How Green Became Good. Urbanized Nature and the Making of Cities and Citizens; University of Chicago Press: Chicago, IL, USA, 2020.

44. Aalto, H.E. Projecting Urban Natures. Investigating Integrative Approaches to Urban Development and Nature Conservation. Doctoral Thesis, Architecture and the Built Environment-The Royal Institute of Technology in Stockholm, Stockholm, Sweden, 2017.

45. Bush, J.; Doyon, A. Building urban resilience with nature-based solutions: How can urban planning contribute? Cities 2019, 95, 1-8. [CrossRef]

46. Mendes, R.; Fidélis, T.; Roebeling, P.; Teles, F. The Institutionalization of Nature-Based Solutions-A Discourse Analysis of Emergent Literature. Resources 2020, 9, 6. [CrossRef]

47. Wacquant, L. Critical Thought as Solvent of Doxa. Constellations 2004, 11, 97-101. [CrossRef]

48. Morgan, T. Alienated Nature, Reified Culture: Understanding the Limits to Climate Change Responses under Existing Socioecological Formations. Political Econ. Commun. 2017, 5, 30-50.

49. Lefebvre, H. Le droit à la ville; Anthropos: Paris, France, 1968.

50. Lefebvre, H. Espace et politique; Anthropos: Paris, France, 1973.

51. Aroul, R.R.; Rodriguez, M. The Increasing Value of Green for Residential Real Estate. J. Sustain. Real Estate 2017, 9, 112-130. [CrossRef]

52. São Paulo (Municipality). Relatório de localização dos Objetivos de Desenvolvimento Sustentável na cidade de São Paulo; Agência Frutífera: São Paulo, Brazil, 2020.

53. Marcuse, P. Gentrification, Abandonment, and Displacement: Connections, Causes, and Policy Responses in New York City. Wash. U.J. Urb. Contemp. L. 1985, 28, 195-240.

54. Atkinson, R. Does Gentrification Help or Harm Urban Neighbourhoods? An Assessment of the Evidence-Base in the Context of the New Urban Agenda. Urban Studies 2002, 1-26.

55. IBGE Cid@des. Available online: https:/ / cidades.ibge.gov.br/ (accessed on 16 March 2021).

56. Fundação SEADE. Pesquisa SEADE. Available online: https://www.seade.gov.br/wp-content/uploads/2020/01/PesquisaSEADE_Aniversario-SP_23jan2020.pdf (accessed on 16 March 2021).

57. São Paulo (Municipality). Lei 15.941. 23/12/2013. Available online: http://legislacao.prefeitura.sp.gov.br/leis/lei-15941-de-23 -de-dezembro-de-2013/detalhe (accessed on 16 March 2021).

58. São Paulo (Municipality). Lei 16.402/16. 22/03/2016. Available online: https://gestaourbana.prefeitura.sp.gov.br/marcoregulatorio/zoneamento/arquivos (accessed on 16 March 2021).

59. Proprietário Direto. Available online: www.proprietariodireto.com.br/preco-m2/consolacao-sao_paulo (accessed on 22 March 2021).

60. Olha Augusta. Available online: https:/ / www.olharaugusta.com/ (accessed on 25 March 2021).

61. Faça tudo a pé em frente ao Parque Augusta-You, Central Park. Available online: https://www.youinc.com.br/ empreendimento/you-central-park-venda-apartamento-studio-1-2-dormitorios-consolacao-rua-caio-prado-sao-paulo-sp/ (accessed on 25 March 2021).

62. Canteiro Vivo Parque Augusta. Available online: https://parqueaugusta.hotglue.me/ (accessed on 22 March 2021).

63. Organismo Parque Augusta. Available online: https:/ / issuu.com/organismopa (accessed on 22 March 2021).

64. Parque Augusta. Available online: https://www.facebook.com/parqueaugustaja (accessed on 22 March 2021).

65. Aliados do Parque Augusta. Available online: https://www.facebook.com/parqueaugusta (accessed on 22 March 2021).

66. Parque Augusta Já. Available online: https://www.youtube.com/channel/UC9yKjcq4_CH-7pkBby_B6bQ/featured (accessed on 22 March 2021).

67. Amâncio, T. Construtoras e prefeitura de SP fecham novo trato sobre parque Augusta Administração municipal e empresas disputam área verde no centro da cidade. Available online: https://www1.folha.uol.com.br/fsp/fac-simile/2018/08/11 (accessed on 16 March 2021).

68. Zylberkan, Mariana. Empreiteiras podem lucrar até R\$95 milhões com acordo do parque Augusta. Available online: https: //www1.folha.uol.com.br/fsp/fac-simile/2018/11/28 (accessed on 16 March 2021).

69. Júnior, S.; Guimarães, A.P.M. Dialética do Parque Augusta. Cidades Verdes 2015, 03, 56-73. [CrossRef]

70. Maróstica, J.R.; Cortese, T.T.P.; Nascimento, A.P.B. Implantação do Parque Augusta: Critérios para unificar as diferentes demandas solicitadas pela população. In Anais do VII SINGEP. In Proceedings of the VII SINGEP, São Paulo, Brazil, 22-23 October 2018; Uninove: São Paulo, Brazil; pp. 1-17.

71. Rolnik, R. Parque Augusta 100\% público. Available online: https://raquelrolnik.blogosfera.uol.com.br/2019/04/05/parqueaugusta-100-publico/ (accessed on 16 March 2021). 
72. Rolnik, R. Mitos e verdades sobre o Parque Augusta. Available online: https://raquelrolnik.wordpress.com/2015/01/29/mitose-verdades-sobre-o-parqueaugusta / (accessed on 16 March 2021).

73. Antunha, A.; Entini, C.E. Parque na Augusta: Um impasse de 40 anos. Available online: https://acervo.estadao.com.br/noticias/ acervo, parque-na-augusta-um-impasse-de-40-anos,9208,0.htm (accessed on 26 March 2021).

74. Pissardo, F.M. A rua Apropriada: Um Estudo Sobre as Transformações e usos Urbanos na Rua Augusta (São Paulo, 1891-2012). Master's Thesis, Architecture-USP, São Paulo, Brazil, 2013.

75. Pinho, M. Construtoras querem mudar área tombada para erguer prédios em SP. Empresários pretendem construir em terreno na Rua Augusta. Moradores, porém, pedem criação de um parque no local. Available online: http://g1.globo.com/sao-paulo/ noticia/2012/03/construtoras-querem-mudar-area-tombada-para-erguer-predios-em-sp.html (accessed on 26 March 2021).

76. Brito, G.; Silva Junior, P. Luta pelo Parque Augusta dialoga com todas as pautas pelo direito à cidade. Available online: https: / / www.correiocidadania.com.br/index.php?option=com_content\&view=article\&id=10615:manchete230315\&catid=63: brasil-nas-ruas\&Itemid=200 (accessed on 26 March 2021).

77. Arquitetura da Gentrificação. Available online: https:/ / www.catarse.me/ag\#about (accessed on 22 March 2021).

78. Jardim, M.H. O Parque é na Rua: A (in)visibilidade da ocupação do Parque Augusta. Available online: https: / / research.uca.ac. uk/5254/1/1\%20O_Parque_e_na_Rua_A_in_visibilidade_da_o.pdf (accessed on 26 March 2021).

79. Rossi, M. Parque Augusta levanta acampamento. Available online: https://brasil.elpais.com/brasil/2015/03/04/politica/1425 486632_591073.html (accessed on 26 March 2021).

80. Scatolini, L.; Bampa, G. Um chamado à liberdade: Ocupe o Parque Augusta. Available online: http://vaidape.com.br/2015/03/ um-chamado-liberdade-ocupe-o-parque-augusta/ (accessed on 26 March 2021).

81. Rolnik, R. y Saule Júnior. N. Estatuto da cidade: Guia para implementação pelos municípios e cidadãos; Caixa/Instituto Polis: Brasília, Brazil, 2002.

82. Iwaszuk, E.; Rudik, G.; Duin, L.; Mederake, L.; Davis, M.; Naumann, S.; Wagner, I. Addressing Climate Change in Cities—Catalogue of Urban Nature-Based Solutions; Sendzimir Foundation: Warsaw, Poland, 2019.

83. International Union for Conservation of Nature and Natural Resources (IUCN). Global Standard for Nature-Based Solutions. A User-Friendly Framework for the Verification, Design and Scaling Up of NbS; IUCN: Gland, Switzerland, 2020.

84. Somarakis, G.; Stagakis, S.; Chrysoulakis, N. (Eds.) ThinkNature Nature-Based Solutions Handbook; Hellas-FORTH: Heraklion, Greece, 2019. [CrossRef]

85. São Paulo (Municipality). Apresentação Projetos Parque Augusta. 04/08/2017. Available online: http://www.capital.sp.gov.br/ arquivos/pdf/pmsp_smj_projetos_parque_augusta_apresentacao_20170804a.pdf/view (accessed on 16 March 2021).

86. São Paulo (Municipality). Prefeitura de São Paulo assina escritura do terreno do futuro Parque Augusta. Available online: http: //www.capital.sp.gov.br/noticia/prefeitura-de-sao-paulo-assina-escritura-do-terreno-do-futuro-parque-augusta (accessed on 16 March 2021).

87. Atas Conselho Gestor Augusta. Available online: https://www.prefeitura.sp.gov.br/cidade/secretarias/meio_ambiente/ parques / conselhos_gestores/index.php?p=302809 (accessed on 22 March 2021).

88. Quintela, S. Prometido para julho, Parque Augusta agora tem discórdia por arquibancada. Available online: https://vejasp.abril. com.br/cidades / capa-parque-augusta/ (accessed on 26 March 2021).

89. Habermas, J. Toward a Rational Society: Student Protest, Science, and Politics; Beacon Press: Boston, MA, USA, 1970.

90. Horkheimer, M.; Adorno T, W. Dialectic of Enlightenment; Stanford University Press: Stanford, CA, USA, 2002.

91. Marcuse, H. One Dimensional Man: Studies in the Ideology of Advanced Industrial Society; Beacon Press: Boston, MA, USA, 1991.

92. Anguelovski, I.; Connolly, J.J.T. Green gentrification in Barcelona. In Renaturing Cities. Town Planning and Housing; Ballester, E.J., Ed.; Barcelona Provincial Council's Press and Communication Office: Barcelona, Spain, 2019; pp. 100-112.

93. Ali, L.; Haase, A.; Heiland, S. Gentrification through Green Regeneration? Analyzing the Interaction between Inner-City Green Space Development and Neighborhood Change in the Context of Regrowth: The Case of Lene-Voigt-Park in Leipzig, Eastern Germany. Land 2020, 9, 24. [CrossRef]

94. Pearsall, H. From brown to green? Assessing social vulnerability to environmental gentrification in New York City. Environ. Plan C Politics Space 2010, 28, 872-886. [CrossRef]

95. Dooling, S. Ecological Gentrification: A Research Agenda Exploring Justice in the City. IJURR 2009, 33, 621-639. [CrossRef]

96. Hahn, T.; McDermott, D.; Ituarte-Lima, C.; Schultz, M.; Green, T.; Tuvendal, M. Purposes and degrees of commodification: Economic instruments for biodiversity and ecosystem services need not rely on markets or monetary valuation. Ecosystem Services 2015, 16, 74-82. [CrossRef]

97. Prieto, M. Practicing costumbres and the decommodification of nature: The Chilean water markets and the Atacameño people. Geoforum 2016, 77, 28-39. [CrossRef]

98. Bond, P. Water commodification and decommodification narratives: Pricing and policy debates from Johannesburg to Kyoto to Cancun and back. Capitalism Nature Socialism 2004, 15, 7-25. [CrossRef]

99. Rowland-Shea, J.; Doshi, S.; Edberg, S.; Fanger, R.; The Nature Gap. Confronting Racial and Economic Disparities in the Destruction and Protection of Nature in America. Available online: https://www.americanprogress.org/issues/green/reports / 2020/07/21/487787/the-nature-gap/ (accessed on 28 March 2021).

100. Byrne, J. When green is White: The cultural politics of race, nature and social exclusion in a Los Angeles urban national park. Geoforum 2012, 43, 595-611. [CrossRef] 
101. Strife, S.; Downey, L. Childhood Development and Access to Nature: A New Direction for Environmental Inequality Research. Organ Environ. 2009, 22, 99-122. [CrossRef]

102. Grimm, N.B.; Schindler, S. Nature of Cities and Nature in Cities: Prospects for Conservation and Design of Urban Nature in Human Habitat. In Rethinking Environmentalism: Linking Justice, Sustainability, and Diversity; Lele, S., Brondizio, E.S., Byrne, J., Mace, G.M., Martinez-Alier, J., Eds.; MIT Press: Cambridge, MA, USA, 2018; pp. 99-125.

103. Frantzeskaki, N. Seven lessons for planning nature-based solutions in cities. Environ. Sci. Policy 2019, 93, 101-111. [CrossRef]

104. Mok, S.; Mačiulytė, E.; Bult, P.H.; Hawxwell, T. Valuing the Invaluable(?) A Framework to Facilitate Stakeholder Engagement in the Planning of Nature-Based Solutions. Sustainability 2021, 13, 2657. [CrossRef]

105. Arlati, A.; Rödl, A.; Kanjaria-Christian, S.; Knieling, J. Stakeholder Participation in the Planning and Design of Nature-Based Solutions. Insights from CLEVER Cities Project in Hamburg. Sustainability 2021, 13, 2572. [CrossRef]

106. Longato, D.; Geneletti, D. Nature-based solutions: New challenges for urban planning. Book of Papers. In Proceedings of the AESOP 2019 Conference Planning for Transition, Venice, Italy, 9-13 July 2019; pp. 3785-3792.

107. Kabisch, N.; Frantzeskaki, N.; Pauleit, S.; Naumann, S.; Davis, M.; Artmann, M.; Haase, D.; Knapp, S.; Korn, H.; Stadler, J.; et al. Nature-based solutions to climate change mitigation and adaptation in urban areas: Perspectives on indicators, knowledge gaps, barriers, and opportunities for action. Ecol. Soc. 2016, 21, 1-15. [CrossRef]

108. Souza, M.L. Fobópole: O medo generalizado e a militarização da questão urbana; Bertrand Brasil: Rio de Janeiro, Brazil, 2008. 